once more to the case of pigment in relation to light. F,r thousands of generations no pigment has been developed, say, on the lower side of a flat fish, no light having fallen on it. The skin is experimentally expo-el to light, and pigment appears: therefore the acquired character of absence of pigment, after thousands of generations, has produced no hereditary change, has not altered the potentialities of the tissue. The argument is fallacious, because the question of how much pig. ment is entirely ignored, and also the question how long the development of pigment experimentally takes. The force of the argument is entirely on the other side. Assume in this case, as Prof. Lankester does in his general argument, that the old character, the absence of pigment, is an acquired character. Then experiment has shown that this character is inherited: that is to say, the action of light obviously overcomes a resistance in producing pigment, and after years does not produce as much as on the upper side is present from the beginning. This resistance can be nothing else than herelity, the inheritance of a tendency to pigmentlessness. Therefore the acquired character is inherited. It is undeniable and indisputable that the argument propounded by Prof. Lankester proves the inheritance of acquired characters, if it is properly applied in accordance with the facts. This is on the assumption that the "old characters" are acquired. If they are not acquired, the argument has no force at all. The facts allow us to say that the tendency to pigmentlessness, or the resistance to the development of pigment on the lower side of a flounder, is certainly inherited, but whether or not it is due to the absence of light during many successive generations we do not know. As Sir Edward Fry says, if we by definition confine the term "acquired character" within the limits of an individual history, then of course an acquired character can never be inherited. The question is whether the conditions which produce a change in the individual can affect the offspring? The experimental investigation must take the following course. Suppose a given amount of stimulation $\mathrm{X}$ to act upon individuals in successive generations, producing in the first generation a result $x$. Then the question is if $\mathrm{X}$ remains the same, does $x$ remain constant or not? If there is no inherited effect, then $x$ must remain constant in all succeeding generations. If $x$ increases by some amount, however small, and becomes $x+a$, then $a$ is not acquired by the individual, but inherited, and it is clear that the result will go on increasing to $x+2 a, x+3^{a}$, and so on to $x+n a$, where $n$ represents the number of generations. In my own opinion, there is evidence that something of this kind does occur, though definite investigations are much to be desired.

Plymouth, January $\mathrm{I}$. J. T. Cunningham.

As one who has been reading the discussion in your pages on the meaning of the term "acquired characters," I may perhaps be permitted to direct attention to the history of the term. It was first used with reference not to species but to individuals. Every character of an individual is either derived from the fecundated ovum or acquired during life. This was obvious; and the question arose: Could acquired characters be transmitted? As long as the term is applied to an individual, it has that kind of precision which is desirable in all scientific terminology, namely, that it perfectly explain; itself.

Glasgow, January I2. John Cleland.

\section{Chinese Theories of the Origin of Amber.}

IN my letter on "Some Oriental Beliefs about Bees and Wasps" (NATURE, vol. 1. p. 30, May Io, I894), I have traced the origin of the Chinese belief in the production of amber from bees into the presence in amber of hymenoptorous remains. Apparently developed from this belief, there is another misconception recorded by Cháng Hwá (killed 300 A.D.), whose passage on the subject reads as follows : "In 'Shinsien-chuè, ' it is said, the resins of the pine and arbor-vitæ, after remaining underground for one thousand years, are turned into Pachyma $\operatorname{cocos}$ (Fuh-ling), ${ }^{1}$ which is turned into amber.' Notwithstanding this statement, the Mount Tai produces Pachyma, but no amber; whereas Yung-chang.... produces amber, but no Pachyma. Another theory is that amber is made by burning the honey-combs. Which is true of these two theories is not yet
decided."

Of all Chinese theories propounded to account for the origin

1 Identified thus in Dr. K. Itô's "N Nihon Sambutsu-shi," part vii

"Póh-wuh-chi," tom. iv., sub. "Yón-wuh."

No. I 317 , vOL. 517 of amber, the most veracious one is given in Li Shi-Chin's work, ${ }^{3}$ thus: "Amber originates in the resin of pines; when the pines, with their branches and knots luxuriantly growing, were heated by the sun, the resin came out of the wood; it coagulated after days and sunk underground, and after undergoing subterraneous changes, left behind the lustrous substance [which is amber]. In this condition still it has in it the tenacity of resin, so that when it is rubbed and warmed between the palms, it can pick up particles of dust. Those insects in its enclo:ure had cohered with it before its sinking underground."

Besides the resin of pines, the exudation from the "Fung" (Liquidambar Maximowiczii) is asserted by Kán Páu-Shing (lived in the tenth century A.D.) to be a nascent form of amber, ${ }^{4}$ the opinion well coinciding with the Western idea that has given to styrax the name "Liquidambar." 5

In "Shi shwoh" (written in the fifth century A.D.) amber is said to be formed from the subterraneous metamorphosis of the gum of peach trees, ${ }^{6}$ which reminds us of the simile, "Like gum from the cherry," used by Pliny in his exposition of the resinous origin of amber. ${ }^{7}$

Some other theories are full of absurdity. One of these holds that the dragon's blood buried underground turns to amber, and the demon's to agate ${ }^{8}$ Also, the etymological origin of "Hú pèh," the Chinese name for amber, is involved in myth. In ancient times this word was written in two letters, together signifying "Tiger's Soul," which is explained in this way: "At night the tiger applies its one eye for illumination, and another for vision. When it is shot with arrow the light of the eye, which is the tiger's soul, sinks underground, and turns into a white stone. . . A Amber resembles this stone; hence the name." 3

According to "Hwái-nán-tze" (written in the second century B.C.), "the dodder is the outgrowth of amber." 10 Almost inexplicable as this story may appear, I have found certain clues to its elucidation. Káu Yú (lived in the second century A.D.) gives "Nii-ló" (i.e. Usnea longissima)"11 as a synonym of "Tú-sze" (i.e. the dodder)." From this it is evident that the early Chinese have confounded Usnea with dodder-the confusion caused by the superficial resemblance and similar habitats of the two plants. ${ }^{13}$ Now, there is a Chinese belief recorded about 240 B.C., that Pachyma cocos is the root of dodder, ${ }^{1+}$ which has doubtless grown out of the common occurrence upon and under the pines of the Usnea and Pachyma. And as this Pachyma had been held as an intermediary phase through which resins were to pass into amber (see above), it would seem that the story which affirms the dodder to be the outgrowth of amber, was not inconsistent with the understanding of the early Chinese theorisers.

January II.

\section{Rhynchodemus Terrestris in Germany.}

IN NATURE of October 25, 1894 (p. 617), Mr. Scharff mentioned Rhynchodemus terrestris, as stated, in Germany, near Wuirzburg, by Semper. It would seem that the worm was exceedingly rare. But I found it repeatedly at several points of Saxnny and Thuringia, in the mountains and in the plain, in leaved and fir wood, under moss or dead leaves. Sufficient attention would detect it without doubt in many regions. Recently Mr. Ehrmann found several specimens feeding on a dead Arion empiricorum. Leipzig.

The "Proceedings of the Chemical Society."

THE title-page and index of this periodical have just come to hand, and on the title-page occur the words, "Edited by the Secretaries." It appears to me right that authors should know

\section{3 " Pan-tsau Káng-muh," ${ }_{57} 8$, art. " Hú-pèh."}

4 rbid.

5 Loudon, "Encycloprerlia of Plants," 1880 , p. 798.

6 Twan Chìng-Shih, "'Yú- áng T'sáh-tsú," toin. xi.

7 "Nalural His'ory," English translation, Bohn's edition, vol. vi., p. 401 8 Twan Ching-Shih. loc. cit.

9 "Pan-tsau Káng-muh," loc. cit. and art. "Hú."

10 Twan Ching.Snih, nbì supp

11 Identified thus in Dr. M. Miyoshi's article in the Shokubutsugakn Zasshi, No. 34, p. 435, ,Tōkyō, Dec. ro, I 889

12 "Lü-shi Ćhìn-tsiú," Japanese edition, N.D., tom. ix. p. 9, Káu Yú's

${ }^{13}$ Cháng Hwá appears to have well distinguished the two plants. $\mathrm{He}$ says, "IJnea lives upon the dodder, and the dodder up on trees." "Púhwuh-chi," loc. cit.

14 "Lïi-shi Chùn-tsiú, loc, cit. text. 